UDC 542.943:661.725.6

\title{
OXIDATIVE DEHYDROGENATION OF CYCLOHEXANOL TO CYCLOHEXANONE CATALYSED BY MODIFIED ZEOLITE CATALYST
}

\author{
Z.A.Shabanova \\ M.Nagiyev Institute of Catalysis and Inorganic Chemistry, NAS of Azerbaijan
}

zumrud-042425-@mail.ru

Received 08.04.2020

Accepted 15.07.2020

\begin{abstract}
Gas-phase oxidative dehydrogenation at atmospheric pressure and a temperature of $260-370^{\circ} \mathrm{C}$ in the presence of a modified zeolite catalyst clinoptilolite cyclohexanol with a conversion of $90-99 \%$ was oxidized to cyclohexanone with the selectivity of $96-98 \%$. It has been studied kinetic laws of the reaction.
\end{abstract}

Keywords: oxidative dehydrogenation, cyclohexanol, cyclohexanone, modified clinoptilolite.

doi

\section{Introduction}

Cyclohexanone, a large-capacity product of organic and petrochemical syntheses, is widely used in the production of polyamide plastics, synthetic fibers and biologically active preparations [1]. In this regard, the scale of its production is increasing annually. On an industrial scale, cyclohexanone is mainly obtained by oxidation of cyclohexane with atmospheric oxygen at elevated pressure, mainly in the presence of homogeneous catalysts - soluble cobalt salts $[2,3]$.

In previous works [3-8] we found that zeolites modified by metal cations by the ion exchange method exhibit relatively high catalytic activity and selectivity in the oxidative reactions of aliphatic alcohols at relatively low temperatures $\left(250-350^{\circ} \mathrm{C}\right)$. The use of multifunctional metal-zeolite catalysts in these reactions leads to a reduction in the consumption of raw materials, lower operating costs for the isolation and purification of the resulting product, and environmental protection. The development of these processes requires a detailed study of the mechanism of these reactions proceeding.

The aim of this present work is to study the catalytic activity of the modified zeolite in the oxidative dehydrogenation of cyclohexanol and to investigate the kinetic laws of the reaction.

\section{Experimental part}

The test of the activity of the metalzeolite catalysts and a study of the kinetic regularities of the reactions was carried out in a flow device with the quarts tube reactor connected directly to the gas chromatograph at atmospheric pressure, in the temperature range $260-370^{\circ} \mathrm{C}$, space velocities by the alcohol $0.91-7.0 \mathrm{~h}^{-1}$, molar ratios of reagents $\mathrm{C}_{6} \mathrm{H}_{11} \mathrm{OH}$ :air $=(0.63-1.3)$ : (5.57-8.1).

Chromatographic analysis of oxidation products was carried out on an "Agilent 7890" chromatograph with an "Agilent-5975" mass detector with HP-5 MS column, $30 \mathrm{~m}$ long, 0.32 $\mathrm{mm}$ in diameter, filled with $5 \%$ phenyl, $95 \%$ methylpolysiloxane. The carrier gas is helium, flow rate $-2 \mathrm{~cm}^{3} / \mathrm{min}$. program control of the temperature from 70 to $180^{\circ} \mathrm{C}$ at a speed of $15^{\circ} \mathrm{C}$ per minute.

To prepare a catalyst based on the natural clinoptilolite it was initially dealuminated. A fraction of the initial zeolite with a grain size of $0.25-0.63 \mathrm{~mm}$ in a sample of $50 \mathrm{~g}$ is taken and processed in a liter flask at stirring with $2 \mathrm{~N}$ $\mathrm{HCl}$ solution (three times for 2 hours) at $T=$ 95-96 ${ }^{\circ} \mathrm{C}$. Cations of transition elements are introduced into the zeolite by the method ion exchange. A specific sample of zeolite with a grain size of $0.25-0.63 \mathrm{~mm}$ is placed in a 1-liter round-bottom flask, into which $100 \mathrm{ml}$ of distilled water is added (until the zeolite is coated) and heated at stirring to $95-98^{\circ} \mathrm{C}$. Then, in this flask, dropwise, chloride solutions of the corresponding transition element are added. This mixture was stirred for 8-16 hours until the ions were completely exchanged. To determine the 
completeness of the exchange, qualitative reactions of the interaction of the introduced ions are used. At the end of the exchange, the catalyst is washed from the $\mathrm{Cl}^{-}$ions with distilled water and dried at $T=150^{\circ} \mathrm{C}$. Before the study, the powdery zeolite was pressed into tablets with a diameter of $10 \mathrm{~mm}$, which were crushed with the release of a fraction of $0.25-0.63 \mathrm{~mm}$. Then the catalyst was activated by air purging at a feed rate of $2400 \mathrm{~h}^{-1}$ for 2 hours at $T=350$ $400^{\circ} \mathrm{C}$, then the temperature decreased to the reaction temperature and the system was purged with nitrogen within one hour. The experiments showed that after preliminary processing of the catalyst, the latter worked stably, that was systematically verified during the study by control experiments confirming the reproducibility of the results.

The amount of introduced elements into the clinoptilolite composition was determined by ion spectral analysis on an "Agilent 7700 ICP-MS". We used catalysts with a particle size of $0.25-0.63 \mathrm{~mm}$.

\section{Results and its discussion}

Table 1 shows the experiments results of synthesized catalysts in the cyclohexanol oxidation reaction at a space velocity of $2363 \mathrm{~h}^{-1}$ and the molar ratio of cyclohexanol: air =1.1: 6.7.

As can be seen from Table 1, the initial clinoptilolite exhibits a relatively low catalytic activity in the studied reaction. Modification of zeolite leads to an increase the catalyst activity. The results of the studies allow us to conclude that the most highly efficient catalyst for this reaction among the studied catalytic systems at the studied process parameters is the catalyst $\mathrm{CuPdSn}-$ clinoptilolite $\left(0.5 \% \mathrm{Cu}^{2+}, 0.15 \% \mathrm{Pd}^{2+}, 0.5 \% \mathrm{Sn}^{2+}\right)$.
A study of the kinetic laws of the reaction was carried out under the following conditions: temperature $-260-370^{\circ} \mathrm{C}$; the space velocity of reaction mixture $(V)$ is $1036-3109 \mathrm{~h}^{-1}$; partial pressure $\left(P_{\text {alcohol }}\right)-0.06-0.24$ atm and $\left(P_{\mathrm{O}_{2}}\right)-$ $0.05-0.24$ atm. Tables 2,3 present the results of a study of the kinetic laws of the oxidative dehydrogenation of cyclohexanol on the selected active catalyst ( $\mathrm{CuPdSn}$-clinoptilolite).

Data in Table 2 that show, at a space velocity of $2073 \mathrm{~h}^{-1}$, at a constant $P_{\text {alcohol }}(0.12$ atm) and a variation of $P_{\mathrm{O}_{2}}$ from 0.05 to 0.24 atm, the maximum ketone yield is reached at $P_{\mathrm{O}_{2}}=0.18 \mathrm{~atm}$ at all studied temperatures. A further increase in $P_{\mathrm{O}_{2}}$ from 0.18 to $0.24 \mathrm{~atm}$ leads to a decrease in the yield of cyclohexanone. In the entire range studied, with an increase in the partial pressure of oxygen, the yields of the reaction products - methylcyclopentene, 2-cyclohexen-1-one, carbon dioxide, and cyclohexane conversion increase, and the cyclohexene yield decreases.

From the Table 3 it can be seen that at constant $P_{\mathrm{O}_{2}}(0.17 \mathrm{~atm})$ and with an increasing of $P_{\text {alcohol }}$ from 0.06 to 0.12 atm, the yield of cyclohexanone increases and reaches a maximum. A further increase in $\mathrm{P}_{\text {alcohol }}$ leads to a decrease in the yield of cyclohexanone. A decrease in the yield of ketone is accompanied by an increase in the yield of cyclohexene and methylcyclopentene and a decrease in the conversion of alcohol and the yields of 2-cyclohexen-1-one and carbon dioxide. This is explained by the fact that at a given partial oxygen pressure, the relatively high partial pressures of cyclohexanol prevent the coordination of oxygen with the active sites of the metal zeolite catalyst.

Table 1. Activity of synthesized catalysts

\begin{tabular}{|c|c|c|c|c|c|c|}
\hline \multirow{2}{*}{ Catalyst } & \multicolumn{3}{|c|}{ Concentration of cations, $\%$} & \multirow{2}{*}{$T,{ }^{0} \mathrm{C}$} & \multirow{2}{*}{ Conversion, $\%$} & \multirow{2}{*}{ Selectivity, \% } \\
\hline & $\mathrm{Sn}$ & $\mathrm{Pd}$ & $\mathrm{Cu}$ & & & \\
\hline Clin. & - & - & - & 300 & 85.4 & 17.1 \\
\hline Clin. (treat. $\mathrm{NH}_{4} \mathrm{OH}$ ) & - & - & - & 280 & 98.0 & 27.4 \\
\hline Clin. (treat. $\mathrm{NH}_{4} \mathrm{OH}$ ) & - & - & - & 320 & 96.8 & 50.9 \\
\hline Clin. & & 0.1 & 0.5 & 330 & 77.1 & 75.8 \\
\hline Clin. & 0.5 & 0.15 & 0.5 & 245 & 80.8 & 92.2 \\
\hline Clin. & 0.5 & 0.15 & 0.5 & 335 & 99.5 & 96.6 \\
\hline
\end{tabular}


Table 2. The influence of the partial pressure of oxygen on the oxidative dehydrogenation of cyclohexanol $\left(V=2073 \mathrm{~h}^{-1}\right.$; $V_{\mathrm{O}_{2}}=0.55 \mathrm{l} / \mathrm{h} ; n_{\mathrm{o}_{2}}^{0}=0.04785 \mathrm{~mole} / \mathrm{h} ; P_{\mathrm{O}_{2}}=0.17 \mathrm{~atm} ; G_{\mathrm{cat}}=2.94 \mathrm{~g}$ )

\begin{tabular}{|c|c|c|c|c|c|c|c|c|}
\hline \multirow{2}{*}{$T,{ }^{0} \mathrm{C}$} & \multicolumn{2}{|c|}{$\begin{array}{c}\text { Partial pressure, } \\
\text { atm. }\end{array}$} & \multirow{2}{*}{$\begin{array}{c}\text { Conversion, } \\
\%\end{array}$} & \multicolumn{5}{|c|}{ The yield of the reaction products, $\%$} \\
\hline & $\mathrm{PO}_{2}$ & $P_{\mathrm{N}_{2}}$ & & Cyclohexene & Cyclohexanone & $\begin{array}{c}\text { Methyl } \\
\text { cyclopenthene }\end{array}$ & $\begin{array}{c}\text { Cyclohexyl } \\
\text { cyclohexanone-1 }\end{array}$ & $\mathrm{CO}_{2}$ \\
\hline 260 & 0.05 & 0.83 & 49.7 & 2.9 & 38.5 & 0.9 & 7.4 & - \\
\hline 260 & 0.13 & 0.75 & 75.5 & 1.8 & 54.7 & 1.1 & 17.9 & - \\
\hline 260 & 0.17 & 0.71 & 90.42 & 1.1 & 65.5 & 1.9 & 21.9 & 0.02 \\
\hline 260 & 0.24 & 0.64 & 94.2 & 0.5 & 65.8 & 3.7 & 23.8 & 0.4 \\
\hline 320 & 0.13 & 0.75 & 90.41 & 3.2 & 81.1 & 3.6 & 2.5 & 0.01 \\
\hline 320 & 0.17 & 0.71 & 97.38 & 1.8 & 88.7 & 4 & 3.3 & 0.08 \\
\hline 320 & 0.24 & 0.64 & 99.4 & 0.5 & 89.3 & 4.9 & 3.9 & 0.8 \\
\hline 350 & 0.13 & 0.75 & 92.8 & 2.3 & 87.9 & 1.9 & 0.5 & 0.2 \\
\hline 350 & 0.17 & 0.71 & 99.2 & 1 & 94.4 & 2.1 & 1.1 & 0.6 \\
\hline 350 & 0.24 & 0.64 & 100 & 0.1 & 94.7 & 2.5 & 1.5 & 1.2 \\
\hline 370 & 0.13 & 0.75 & 95.4 & 2 & 86.6 & 1.4 & - & 5.4 \\
\hline 370 & 0.17 & 0.71 & 100 & 0.4 & 91.8 & 1.7 & 0.2 & 5.9 \\
\hline 370 & 0.24 & 0.64 & 100 & - & 90.5 & 1.9 & 0.7 & 7.3 \\
\hline
\end{tabular}

Table 2. The influence of the partial pressure of cyclohexanol to the oxidative dehydrogenation of cyclohexanol $(V$ $\left.=2073 \mathrm{~h}^{-1}, V_{\mathrm{O}_{2}}=0.55 \mathrm{l} / \mathrm{h} ; n_{\mathrm{o}_{2}}^{0}=0.04785 \mathrm{~mole} / \mathrm{h} ; P_{\mathrm{O}_{2}}=0.17 \mathrm{~atm} ; G_{\mathrm{cat}}=2.94 \mathrm{~g}\right)$

\begin{tabular}{|c|c|c|c|c|c|c|c|c|}
\hline \multirow{2}{*}{$T,{ }^{0} \mathrm{C}$} & \multicolumn{2}{|c|}{$\begin{array}{l}\text { Partial pressure of } \\
\text { the reagents, atm }\end{array}$} & \multirow{2}{*}{$\begin{array}{c}\text { Conversion, } \\
\%\end{array}$} & \multicolumn{5}{|c|}{ The yield of the reaction products, $\%$} \\
\hline & $P_{\mathrm{C}_{6} \mathrm{H}_{11} \mathrm{OH}}$ & $P_{N_{2}}$ & & Cyclohexene & Cyclohexanone & \begin{tabular}{|c|} 
Methyl \\
cyclopenthene
\end{tabular} & $\begin{array}{c}\text { Cyclohexyl } \\
\text { cyclohexanone-1 }\end{array}$ & $\mathrm{CO}_{2}$ \\
\hline 260 & 0.17 & 0,67 & 84.1 & 2.1 & 63.4 & 2.5 & 16.1 & - \\
\hline 260 & 0.24 & 0.59 & 75.5 & 3.1 & 60.2 & 3.5 & 8.7 & - \\
\hline 290 & 0.17 & 0,67 & 90.72 & 2.8 & 79.8 & 3.3 & 4.8 & 0.02 \\
\hline 290 & 0.24 & 0.59 & 87.1 & 4.4 & 75.6 & 4.9 & 2.2 & - \\
\hline 320 & 0.06 & 0.77 & 99.1 & 1.5 & 79.5 & 1.7 & 15.7 & 0.7 \\
\hline 320 & 0.12 & 0.74 & 97.88 & 1.8 & 88.7 & 4 & 3.3 & 0.08 \\
\hline 320 & 0.17 & 0,67 & 96.75 & 4.2 & 85.6 & 4.7 & 2.2 & 0.05 \\
\hline 350 & 0.06 & 0.77 & 100 & 0.8 & 86.2 & 1.5 & 9.8 & 1.5 \\
\hline 350 & 0.12 & 0.74 & 99.2 & 1 & 94.4 & 2.1 & 1.1 & 0.6 \\
\hline 350 & 0.17 & 0,67 & 97.1 & 1.7 & 92.9 & 2.8 & - & 0.2 \\
\hline 370 & 0.06 & 0.77 & 100 & - & 84.5 & 1.1 & 6.9 & 7.5 \\
\hline 370 & 0.12 & 0.74 & 100 & 0.4 & 91.8 & 1.7 & 0.2 & 5.9 \\
\hline 370 & 0.17 & 0,67 & 99.8 & 1.5 & 90.9 & 2.5 & - & 4.9 \\
\hline
\end{tabular}

From the above stated results it follows that the optimal partial pressures of the reagents at which the highest yield of cyclohexanone is achieved, are: $P_{\text {alcohol }}=0.12$ atm and $P_{\mathrm{O}_{2}}=0.18$ atm.

From the data Table 2 and 3 it follows that with increasing temperature from 260 to $350^{\circ} \mathrm{C}$, the yield of cyclohexanone increases and reaches a maximum at $350^{\circ} \mathrm{C}$, and a further increase in temperature to $370^{\circ} \mathrm{C}$ leads to a decrease in yield. Alcohol conversion and $\mathrm{CO}_{2}$ yield continuously increase throughout the studied temperature range.

The high selectivity (75-97\%) of the formation of cyclohexanone and the conversion of cyclohexanol (77-99\%) and moderate temperature suggest the proposed catalyst may be of interest for further practical use.

\section{References}

1. Lebedev N.N. Himiia i tekhnologiia osnovnogo organicheskogo i neftehimicheskogo sinteza. M.: Himiia, 1988. $522 \mathrm{~s}$.

2. Frolov A.S., Kurganova E.A., Koshel G.N., Nesterova T.N. Europ. J. Analytical and Applied Chemistry. 2015. No 1. P. 16-22.

3. Koshel G.N., Smirnova E.V., Kurganova E.A., Ekimova I.D., Lebedeva N.V., Koshel S.G. Ka- 
taliz v promy`shlennosti. 2010. No 3. P. 26-29.

4. Aliev A.M., Medzhidova S.M., Sarydzhanov A.A., Shabanova Z.A. i dr. Okislitelnoe degidrirovanie nizshikh alifaticheskikh spirtov $\mathrm{S}_{1}-\mathrm{S}_{4}$ na sinteticheskikh i prirodnykh tceolitakh, modifitcirovannykh kationami perehodnykh metallov. 6aia Vseross. tceolitnaia konf. "Tceolity i mezoporistye materialy: Dostizheniia i perspektivy". Tez. docl. Zvenigorod. 2011. S. 177-179.

5. Alihanova Z.A., Aliev A.M., Sarydzhanov A.A., Bakhmanov M.F. Kinetika okislitelnogo degidrirovaniia izobutilovogo spirta na bimetalltceolitnom katalizatore CuPdNaY. Izv. Vuzov Himiia i him. tekhnol. 2009. № 11. C. 106-110.

6. Aliyev A.M., Shabanova Z.A., Aliyev F.V. Oxida- tive dehydrogenation of hydrocarbons and the partial oxidation of aliphatic alcohols on modified zeolitesю Europ. Appl. Sci. 2015. № 5. P. 67-79.

7. Aliev A.M., Medzhidova S.M., Shabanova Z.A. Podbor metalltceolitnogo katalizatora i kinetika reaktcii okislitelnogo degidrirovaniia nizshikh alifaticheskikh spirtov. Rossiiskii kongress po katalizu ROSKATALIZ. Sb. tez. Novosibirsk. 2011. T. 2. C. 186-192.

8. Aliev A.M., Medzhidova S.M., Sarydzhanov A.A., Matiev K.I. Ionoobmennyi metod modifitcirovaniia tceolitov kationami metallov kak predelnaia model nanesennogo katalizatora. Azerb. him. zhurn. 2011. № 4. S. 9-25.

\title{
MODIFIKASIYA OLUNMUŞ SEOLIT KATALIZATORU ILO TSIKLOHEKSANOLUN TSIKLOHEKSANONA KATALITIK OKSIDLӘŞDIRICI DEHIDROGENLӘŞMӘSI
}

\begin{abstract}
Z.O.Şabanova
Modifikasiya olunmuş seolit katalizatoru iştirakında $260-370^{\circ} \mathrm{C}$ temperaturda qaz fazada oksidkləşdirici dehidrogenləşdirilməklə tsikloheksanol 90-99\% konversiya vo 96-98\% selektivliklə tsikloheksanona oksidləşdirilmişdir. Reaksiyanın getməsinin kinetik qanunauyğunluqları öyrənilmişdir.
\end{abstract}

Açar sözlor: oksidloşdirici dehidrogenlaşmə, tsikloheksanol, tsikloheksanon, modifikasiya olunmuş klonoptilolit.

\section{ОКИСЛИТЕЛЬНОЕ ДЕГИДРИРОВАНИЕ ЦИКЛОГЕКСАНОЛА В ЦИКЛОГЕКСАНОН, КАТАЛИЗИРУЕМОЕ МОДИФИЦРОВАННЫМ ЦЕОЛИТОМ}

\section{3.А.Шабанова}

Газофазным окислительным дегидрированием при атмосферном давлении и температуре $260-370^{\circ} \mathrm{C}$ в присутствии модифицированного цеолитного катализатора циклогексанол с конверсией 90-99 \% был окислен в циклогексанон с селективностью 96-98 \%. Изучены кинетические закономерности протекания реакции.

Ключевые слова: окислительное дегидрирование, ичиклогексанол, ичиклогексанон, модифицированный клиноптилолит. 